\title{
SUBSIDIARY STRATEGY: THE EMBEDDEDNESS COMPONENT
}

\author{
Carlos García-Pont \\ J. Ignacio Canales
}

Fabrizio Noboa 


\title{
SUBSIDIARY STRATEGY: THE EMBEDDEDNESS COMPONENT
}

\author{
Carlos García-Pont* \\ J. Ignacio Canales**
}

Fabrizio Noboa***

\begin{abstract}
This paper inductively derives a model that develops the concept of subsidiary embeddedness as the framework within which subsidiary strategy can take place. Our model identifies three hierarchical levels of embeddedness. Operational embeddedness relates to interlocking day-today relations. Capability embeddedness deals with the development of competitive capabilities for the multinational as a whole. Strategic embeddedness deals with subsidiary participation in the MNC strategy setting. We deem these three types of embeddedness as ways to develop subsidiary strategic alternatives. As such, different types of subsidiary embeddedness imply different subsidiary roles. Embeddedness, as we inductively concluded from a revealing case study, is not merely an outcome of institutional setting, but a resource which a subsidiary can manage by means of manipulating dependencies or exerting influence over the allocation of critical resources. A subsidiary can modify its embeddedness to change its strategic restraints. Therefore, the development of subsidiary embeddedness becomes an integral part of subsidiary strategy.
\end{abstract}

\footnotetext{
* Professor, Marketing, IESE

** Lecturer, University of St Andrews

*** Professor, USFQ Business School
}

Keywords: Multinational management, subsidiary, strategy, organization. 


\section{SUBSIDIARY STRATEGY: THE EMBEDDEDNESS COMPONENT}

\section{Introduction}

Theory and research have suggested that subsidiaries may develop strategy alongside their evolution (Birkinshaw and Hood, 1998; Taggart, 1999; Andersson, Björkman and Forsgren, 2002). At the same time, embeddedness of any firm in its business network has significant implications for its performance (Zukin and DiMaggio, 1990; Uzzi, 1996; Dyer and Singh, 1998; Håkansson and Snehota, 1998; Gulati, Nohria and Zaheer, 2000; Rowley, Behrens and Krackhardt, 2000; Hung, 2002). In fact, embeddedness is a good predictor of the role a subsidiary may play in the overall Multinational Corporation (MNC) network (Andersson and Forsgren, 1996) and the subsidiary's local embeddedness partially explains subsidiary knowledge creation (Taggart and Hood, 1999; Andersson, Björkman and Forsgren, 2005). Subsidiaries, however, have more constraints in developing their own strategy given that they are embedded in different networks that include all other units of the multinational to which they belong, alongside customers, suppliers and other institutions. Moreover, they typically have a pre-set business domain that limits their possible strategy (Birkinshaw and Hood, 1998). Inspite of subsidiaries face corporate and resource constraints, and the establishment of lateral relations between MNC units (Birkinshaw and Morrison, 1995), they actually have space to define their own mission and goals, and look after their own future (Birkinshaw and Hood, 1998), which influences performance (Subramaniam and Watson, 2006). Nevertheless, the process whereby and the extent to which subsidiaries develop their own strategy via embeddedness has been given less attention.

This paper uses the notion of embeddedness to inductively develop a model that contributes to the literature on subsidiary strategy (Birkinshaw and Hood, 1998). The contribution of this paper is to present a model that uses the very embeddedness of the subsidiary as the key driver of subsidiary distinctiveness. We consider distinctiveness an integral part of subsidiary strategy, as it builds the subsidiary's raison d'être within the multinational network (Ghoshal and Bartlett, 1990). Our purpose is to inductively build a theory that links subsidiary embeddedness and subsidiary distinctiveness, explaining how the process of developing its distinctiveness depends on the nature of its embeddedness. We fulfill this purpose through a single longitudinal case study of an automobil components manufacture subsidiary. 


\section{A Preview of the Model}

We argue that the subsidiary embeddedness in the MNC is the basis on which its strategy can be developed, and that the level and type of embeddedness of the subsidiary is a constraint on its ability to develop strategy as it limits its initiative potential. Our focus in this paper is not on the local embeddedness of the subsidiary but on its mirror image, the embeddedness of the subsidiary in the MNC. As our case data shows, the level of subsidiary embeddedness in the MNC accounts for the capacity of the subsidiary to have its own strategy. We develop this argument into a theoretical model presented in Figure 1. Subsidiary embeddedness becomes then an integral part of strategy, as the subsidiary has to eliminate or manage the constraints in order to develop its own strategy.

\section{Figure 1}

A Model of Subsidiary Strategy as Embeddedness

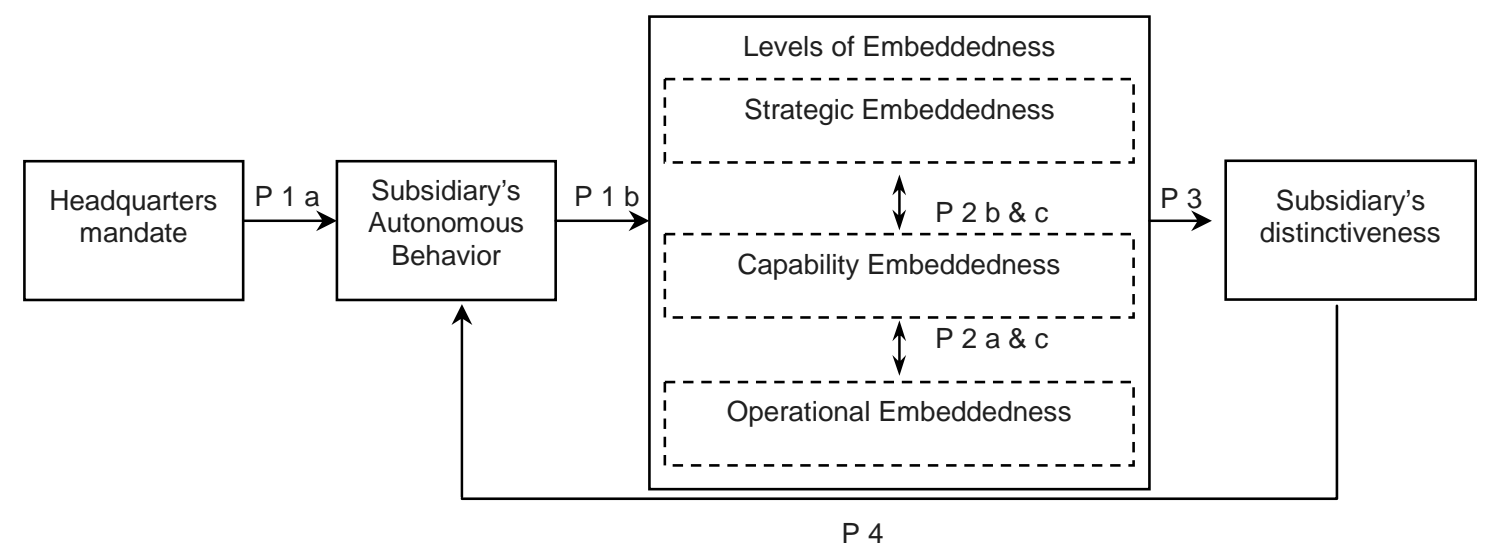

Subsidiaries are paramount to Multinational Corporations' (MNCs) performance. Our central argument is that subsidiary strategy can be traced back to its embeddedness consequences, and we argue that the subsidiary's strategy will be possible only if built on its embeddedness. The study of their contribution to the overall MNC has evolved from a merely passive implementation of head office mandates, towards a more proactive and initiative-taking strategy (Prahalad and Doz, 1981; Hedlund, 1986; Bartlett and Ghoshal, 1989; Birkinshaw, 1997; Birkinshaw and Hood, 1998; Taggart, 1999; Andersson et al., 2002; Birkinshaw, Hood and Young, 2005). Underlying this pattern of research is the prevailing idea that subsidiaries may develop their own strategy by means of two alternatives. On the one hand, the subsidiary may simply fulfill the responsibilities that come from a specific role assigned by headquarters (HQ). Subsidiary strategy may be allocated a subsidiary role (Jarillo and Martínez, 1990). On the other hand, subsidiaries may develop as sources of an MNC's competitive advantage and providers of strategic initiatives, following a more autonomous behavioral pattern (Burgelman, 1983). Subsidiary strategy may then be associated with initiative-taking (Birkinshaw and Hood, 1998; Taggart, 1999; Delany, 2000). Therefore, subsidiary strategy can be seen as a complex balance between HQ's mandate and autonomous behavior. We view subsidiaries as balancing these requirements in as much as they manage embeddedness. In line with Nohria and Ghoshal (1997), we view MNCs as a network of embedded differentiated members. Building on Granovetter (1985) we use embeddedness as the network of relations with other units of the MNC and the market in general. 
The model presented in this paper has four interlinked main elements (see Figure 1). The first element is headquarters' (HQs) mandate, which is exogenous to the model. It may vary from a constrained mandate to a more open guideline shaping the subsidiary's behavior. Second, the autonomous behavior of the subsidiary, which depends on the restrictions set by the mandate. The more leeway the mandate leaves, the more the subsidiary will develop autonomous behavior. Via this behavior the subsidiary can develop embeddedness, which is the capacity of the subsidiary to develop social action, which in turn helps the development of subsidiary strategy. Third, the levels of embeddedness the subsidiary develops through its autonomous behavior. The resulting three levels of embeddedness in ascending order are operational, capability and strategic according to the level of social action achieved. Finally, subsidiary distinctiveness is the outcome variable of the level of embeddedness. Achieving distinctiveness within the MNC contributes to the subsidiary survival and fosters its development. The extent to which distinctiveness is accepted by the MNC's HQ will feed back into the subsidiary's autonomous behavior.

The development of a subsidiary named Brakes Spain, using a case study and network analysis, provides support to develop this inductive model. Due to the delicate nature of the data the names have been disguised. From the case data, we suggest that the subsidiary can manipulate embeddedness as part of its strategy, as it can manipulate other resources. Embeddedness is not only determined by the external factors surrounding the subsidiary, but can also be seen as the result of the autonomous efforts of the subsidiary to stand out for adding value to the overall MNC. The three dimensions of embeddedness proposed here, which the subsidiary can effect in order to increase its strategic importance, are explained next:

Operational embeddedness is viewed here as the set of relations between the subsidiary and other units of the MNC that concern day-to-day activities. Coordination of worldwide manufacturing or product launch gives rise to a network of relations across the MNC whose aim is to keep operational day-to-day activities afloat.

Capability embeddedness is viewed here as the set of relations that comprise the development of strategic capabilities (Teece, Pisano and Shuen, 1997). Benchmarking, best practices or knowledge management efforts highlight the competitive proficiency of certain units. The diffusion of these practices generates a network of relationships among operating units. The more the subsidiary develops these strategic capabilities, the higher the chances of being called to contribute. Overall knowledge management processes will integrate the best actors within the subsidiary to contribute to the different strategic capabilities of the multinational.

Strategic embeddedness is viewed here as the set of relations between the subsidiary and other units of the MNC that relate to the subsidiary's participation in the overall strategy of the MNC. Active participation of subsidiary members in the strategy process may influence the overall MNC's strategy through a group of relations generated from the subsidiary. The more participation there is in the strategic process of the MNC, the more dependencies will be encouraged among the different units in the MNC, and the higher the level of strategic embeddedness.

The proposed model posits an active and important role of subsidiaries in breeding relationships with other members of the MNC. The content of these relationships may range from an operational nature, through capability content all the way to a more strategic character. However, it can also go into a decline in the opposite direction losing either strategic or capability embeddedness due to subsidiary inaction or change in HQ's mandated constraints. 
The remainder of the paper is organized as follows: the next section will introduce the research settings and describe the methods and sources of data. Then we take the reader through the story of the company introducing both qualitative and quantitative data, by virtue of which we develop the theoretical model. Finally, in the last section, we discuss the limitations of our approach, including the relevant boundary conditions, and highlight implications of the model for future MNC research.

\section{METHODS}

This study can better be understood as inductive theory building. We have used a single case study design to study evolution of subsidiary strategy over a ten-year period. The four sources of data, including one quantitative, are presented in Table 1. Informal interactions coupled with participative observation provided the bulk data to construct the story. Participant observation accounts were the result of one author's collaboration with the company studied. This type of data offered depth towards understanding the genesis of strategic behavior in Brakes Spain. In 2003, a second author of this paper collected his qualitative data through interviews in order to be able to cross check the first author's interpretation. We also collected network data and carried out semi-structured interviews in 1998 and 2003. A detailed account of this process together with the research setting follows.

\section{Table 1}

Sources of Data

\begin{tabular}{|c|c|c|c|c|c|c|c|c|c|c|c|c|}
\hline \multirow[b]{2}{*}{ Year } & \multicolumn{5}{|c|}{ Interviews ${ }^{a}$} & \multicolumn{5}{|c|}{ Measurement of Social Network ${ }^{c}$} & \multirow{2}{*}{$\begin{array}{c}\begin{array}{c}\text { Participant } \\
\text { Observation } \\
\end{array}{ }^{\mathrm{e}} \\
\text { Level } \\
\text { Examples }\end{array}$} & \multirow{2}{*}{$\begin{array}{c}\text { Archival Documents } \\
\text { Examples }\end{array}$} \\
\hline & Sub-Total & Top & Man. & $\begin{array}{l}\text { Middle } \\
\text { Man. }\end{array}$ & $\begin{array}{l}\text { Infor- } \\
\text { mants }\end{array}$ & $\begin{array}{c}\text { Sample } \\
\text { (Population) } \\
\text { Resp. rate }\end{array}$ & $\begin{array}{c}\text { Ego-alter } \\
\text { pairs }^{d}\end{array}$ & $\begin{array}{c}\text { Intern } \\
\text { NW }\end{array}$ & Extern NW & Corp NW & & \\
\hline 2003 & 31 & & 23 & 8 & 20 & $\begin{array}{l}84 \\
(1685) \\
95 \%\end{array}$ & 1827 & 1.315 & 232 & 280 & $\begin{array}{l}\text { Top Management } \\
\text { - Planning meeting } \\
\text { - Budgeting meetings } \\
\text { - Brainstorming } \\
\text { sessions } \\
\text { - Assessment and } \\
\text { reporting meetings }\end{array}$ & $\begin{array}{ll}\text { - } & \text { Strategic objectives } \\
\text { - } & \text { Organizational change } \\
& \text { plan } \\
\text { - } & \text { Industry studies } \\
\text { - } & \text { Historic company } \\
& \text { records }\end{array}$ \\
\hline 1998 & 37 & & 22 & 15 & 18 & $\begin{array}{l}50 \\
(1500) \\
96 \%\end{array}$ & 1411 & 734 & 322 & 355 & $\begin{array}{l}\text { Middle Management } \\
\text { - Objective setting } \\
\text { meetings } \\
\text { - Budgeting meetings } \\
\text { - Content developing } \\
\text { meetings } \\
\text { - Product } \\
\text { development } \\
\text { meetings }\end{array}$ & $\begin{array}{l}\text { - Summaries of strategy } \\
\text { meetings } \\
\text { - Communication records } \\
\text { with } \mathrm{HQ} \\
\text { - }\end{array}$ \\
\hline Total & 68 & & 45 & 23 & $23^{b}$ & & & & & & & Total 35 \\
\hline
\end{tabular}

a Data collection included 68 in-depth one to two hour open-ended, in-person interviews with managers of levels 1,2,3 and 4 from the studied organization. These included two interviews each time with each of the three subsidiary CEOs. In 2003, two of these CEOs had left the company, but were still interviewed. Other interviewees were: Plant Managers 1 and 2, Head of Purchasing, Product Testing Manager, Chief Engineering Officer, Human Resources Manager, Client 1 Account Manager, Application Engineering Liaison, Controller Brakes, Spain Quality Manager Purchasing Manager, Product Testing Manager.

5 interviewees, not present in 1998, were interviewed in 2003.

${ }^{c}$ The Social Network was measured in 1998 and 2003; both times via a questionnaire that measured work-based relationships as long term patterns of interaction (Freeman, Romney and Freeman, 1987). Ouestions specifically asked separately for relations with the subsidiary (internal), with the MNC (corporate) and with suppliers or clients (external) (Knoke and Kuklinski, 1982). The sample was selected using a "reputational approach" (Scott, 1991), where information about the actors with higher level of reputation in the set is considered enough to determine the networks of relations of a set. Sampling was required due to both the natural inability of respondents to complement a massive questionnaire and the computational limitations of any network software.

${ }^{d}$ Evident mismatches and incomplete entries were eliminated resulting in $99.2 \%$ of usable data for 1998 and 2003.

${ }^{\mathrm{e}}$ Participant observation was carried out from 1993 to 2003. Through this ten-year period the frequency of interaction ranged from weekly to monthly. These observations were characterized by informal interactions, visits to the company and participation in meetings. 


\section{Research Setting}

Brakes Spain, a subsidiary of British, and managed via its Brakes Division, is the critical case used to inductively develop theory in the present paper. Brakes Spain has undergone an organic process built around the growth and decline of valuable and distinctive resources as illustrated in Birkinshaw and Hood (1998). For this reason, we have chosen it as a revelatory case. Using existing theorization in subsidiary evolution we have inductively developed the theoretical model set forth in the present paper.

British is a diversified MNC, active in more than 30 countries across Europe, America and Asia. Brakes Spain belongs to the brake division within the automotive business, Brakes, a world leader with more than 25 percent volume world market share. Brakes Division is British's largest business and most of the leading vehicle manufacturers utilize their components, operating in 20 countries. Active R\&D is a key element for Brakes Division due to the limited number of customers. Concentration and consolidation of the vehicle manufacturers (Womack, Jones and Roos, 1991) has limited the number of customers for British worldwide.

Turnover of Brakes Spain was in the region of $€ 350$ million in 2001, operating two plants with 1,800 employees. Amongst all Brakes subsidiaries, the Spanish one stands out for three reasons. First, Brakes Spain has been consistently the best performing subsidiary in the Brakes Division, showing the highest return on sales, as well as high flexibility and productivity. Second, all customers' decision centers are located outside Spain, leaving Spain in a disadvantageous position compared to other subsidiaries. This forces Brakes Spain to be especially active in developing its position within the global market and across the MNC. Third and foremost, Brakes Spain has been not only a net cash contributor but also a source of strategic initiatives and capability development for the Brakes Division. As such, Brakes Spain has grown to be a unit of high strategic importance to the MNC.

\section{Data Collection}

Participant Observation: Our involvement with the studied company began in 1993 when one of the authors was invited to take part in a meeting at Brakes Spain. The objective was to review the company's situation and develop a detailed plan for implementing the desired changes. From then until 2003, regular contact with Brakes Spain was maintained at several levels. This included informal interaction, meetings and discussions with managers throughout the company. Participant observation aimed at facilitating strategy formation within Brakes Spain. Regular written notes provided a key resource as a mean of narrating the story. Informal interactions and meetings varied in frequency from weekly to monthly. Weekly interactions took place with contacts across hierarchical levels, from factory foremen through managers to the CEO. The main monthly interactions took place with Brakes Spain's top management. For certain periods of time, there was also frequent interaction with four divisional level managers. Interacting regularly with managers and operational personnel provided data which are not commonly available, and became the basis for narrating the story and articulating the theoretical links that explain it.

Interviews: In parallel, and to gain further and formal understanding of the strategic evolution of the subsidiary, 31 in-depth interviews were carried out in 2003 and 37 in 1998. These interviews took place from March to December 2003 and March to August 1998. On both 
occasions, interviews lasted between 45 minutes and 2 hour, and detailed notes were taken. On both occasions, a protocol was followed as guidance for the sequence of steps to follow and themes to cover aiming at reliability (Yin, 1994). The interviewees were key officers who had a role in the evolution of the subsidiary strategy, as shown in Table 1 . We interviewed 23 managers directly involved with the formulation and implementation of Brakes Spain's strategy. Two researchers were involved in developing the interviews to avoid biased interpretation and to assure coverage of all relevant issues. Throughout the data collection and analysis process, we aimed at internal validity, looking for alternative explanations between the two researchers (Yin, 1994). After each round of interviews, the authors had critical discussions to validate interpretation (Silverman, 2001). Whenever disagreement arose it was sorted out by making a phone call to specific interviewees. This entire process aimed at maintaining reliability and internal validity during qualitative data collection.

Archival data: This included the following documents: first, strategic and organizational documents, at both national and divisional level; second, organizational charts and organizational change plans; third, industry studies and competition reports that analyzed the position of Brakes Spain; fourth, advice and communication records with external consultants; fifth, presentations and communications records with HQ and other business units, as well as historic records of the relationship with customers. These documents were key in cross-checking with the other sources of data.

Social Network Analysis: Our aim was to determine the work-based pattern of relationships that start at the units that make up Brakes Spain, both internally and externally. We included every relevant player within the firm in the sampling. The sampling method was the "reputational approach" (Scott, 1991), where obtaining information about the actors with the higher level of reputation in a particular set of actors is enough to determine the network of relations of that set. This criterion proved useful at Brakes Spain, where managers are the actors with the best knowledge of which agents enjoy the highest level of reputation in the company. Yet, to avoid "hierarchy bias" (tendency to select one's subordinates as enjoying high reputation), the researchers turned to the authors' knowledge of the firm and its employees, and selected those with higher levels of reputation among their peers. The final list was compared to a different one compiled by Brakes Spain's Human Resources Manager, adding or deleting members based on a discussion about his/her actual level of reputation. As a result of this process, 50 managers were selected in 1998 and 84 in 2003. Questionnaires were handed out in the first wave and administered online in the second wave. Questions were formatted in a free-recall and fixed-choice design to allow respondents to name any actor belonging to any unit in Brakes Spain or the MNC with whom he or she had interacted at work in the last six months. Response rates were 95\% and 96\%, for 1998 and 2003, respectively. In both instances, personal calls were made to individuals who were reluctant to respond at first. In both cases a presentation of aggregate network results was made to different units within the company, which also helped to clarify our interpretation of the results.

\section{Data Analysis and Reduction}

Combining participant observation, interview, archival and network data allowed us to understand, not only the relationships between entities, but also the content of those relationships. The analyses of qualitative and quantitative data were carried out separately and hence they are presented next. Both types of data were linked after the analysis to develop our theoretical model. 
Qualitative data: We used various sources of data to develop the Brakes Spain case. For consistency, we triangulated the information obtained through the interviews with the longitudinal database derived from our involvement with the company and the access to archival data (Yin, 1994). To make sense of such a vast amount of data, we focused on constructing the story making use of narrative to consolidate our understanding. Based on the record of participants observation, the two sets of interviews and archival data, the story was written, including the logical links between events. Use of narrative is useful to reduce large amounts of data into a coherent unit (Miles and Huberman, 1994; Pentland, 1999; Silverman, 2001). Interviews and records of participant observation were organized into a sequential timeline matrix (Miles and Huberman, 1994). We classified each segment into one of three time categories, namely, 1993-1998, 1998-2002 and 2002-2003. Next, we devised a written document that logically collated each segment within each time category. Successive iteration, between the matrix and the text, and cross-checking with archival data produced a 34 page draft reporting the story of Brakes Spain. Aiming at reliability, we pursued authentication of the written case by two independent consultants from Brakes Spain (Yin, 1994). They read, revised, and validated the narrative. After a few minor modifications the case in narrative form was deemed an accurate description of the events occurring in Brakes Spain from 1993-2003. A version of this narrative is presented in the present paper. The analysis that logically links operational, capability and strategic embeddedness from the story data can be seen in Table 2 . 


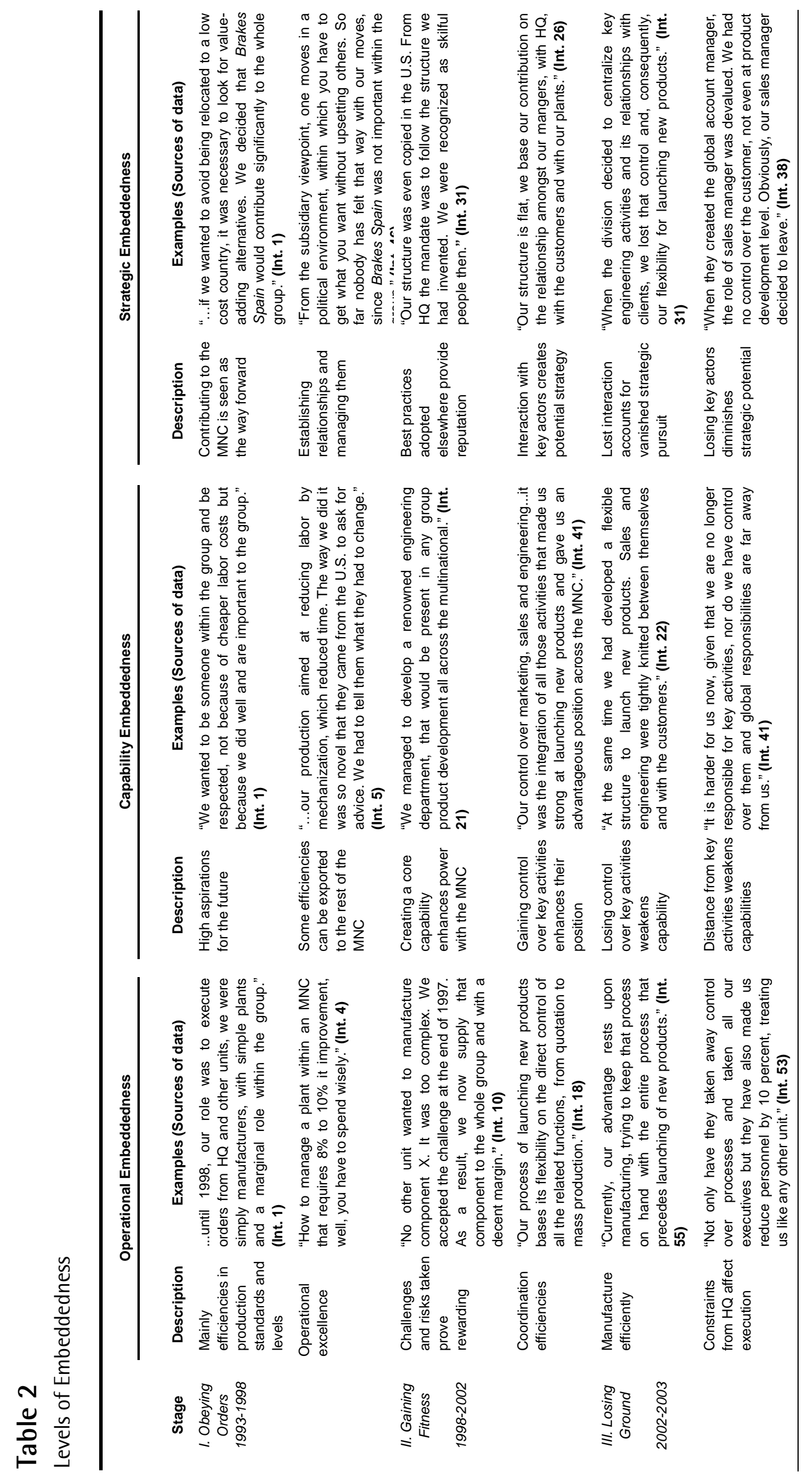


Network Analysis: The issue which recurred most during our interaction with managers was the idea that Brakes Spain was losing contact with different counterparts of the business (other units of the MNC, units of the subsidiary itself, and clients) during the period of study. In order to validate this claim, we performed a network analysis of the relationships starting at Brakes Spain and oriented towards an 'outside' sphere, namely, customers, other operating units within the division and the divisional headquarters. The network was measured in 1998 and in 2003. Structural variables (Wasserman and Faust, 1999) were measured as work-based interactions. Here, we studied actors from two different sets tied by a work-based relationship, one consisting of a sample of employees at Brakes Spain, and a second larger set consisting of employees of the same company plus employees of other units of the MNC, as cited by the interviewees. Actors in the first set are "senders" of the relation (egos), while those in the other set are "receivers" (alters). The second set is opened to who ever senders mention. The resulting network is one made up by ties surrounding the sampled individual units, which can be separated into three more concrete networks. First, the Internal Network made by the relationships between and across units of Brakes Spain. Second, the Corporate Network made by the relations of Brakes Spain with alters, who are members of the MNC. Third, the External Network formed with customers and suppliers. An illustration of these appears in Figure 2. The Internal Network shows the relationships among units within the subsidiary, plant departments or local headquarters departments. The Corporate Network is a two-mode network showing the relationships of the departments within the subsidiary with different departments in other MNC units, including Brakes' division headquarters. The resulting network analysis produced a final database of 1,411 pairs of ego and alter tied by work-based relation entries in 1998 and 1,827 entries in 2003. This was divided into Internal, Corporate and External Networks as can be seen in Table 3. We performed the analysis at the aggregate functional level since we were interested in the relationships between functions rather than between individuals. Next, data were analyzed on cross-tabs, each cell representing the frequency of work-based interactions between ego and alter. To identify the differences between the two networks we calculated the proportion of relations in each network to subsequently test if their differences were significant. The results of such calculations can be seen in Table 3. In addition, we block modeled the two mode Networks (Borgatti and Everett, 1997) and calculated centrality and density measures for the External Network as can be seen in Table 4. All calculations were done using UCINET software for Social Network analysis. 


\section{Table 3}

Evolution of Relations in Brakes Spain

\begin{tabular}{|c|c|c|c|c|c|}
\hline \multirow[b]{3}{*}{ All Ego-Alter Relations (I,II \& III) } & \multicolumn{2}{|l|}{$1998^{a}$} & \multicolumn{2}{|l|}{$2003^{a}$} & \multirow{2}{*}{$\begin{array}{l}1998 \text { vs. } 2003 \\
\hat{p}_{1} \neq \hat{p}_{2}\end{array}$} \\
\hline & Number of Relations & $\hat{p}_{1}$ & Number of Relations & $\hat{p}_{2}$ & \\
\hline & 1,183 & 1 & 1705 & 1 & \\
\hline $\begin{array}{l}\text { I. Internal Network: Operational } \\
\text { and Strategic Relations }\end{array}$ & 734 & 0.62 & 1315 & 0,77 & $(+)^{\star \star \star \star}$ \\
\hline 1) HQ Spain-Plants & 106 & 0.09 & 185 & 0.11 & $(+)$ \\
\hline 2) Plants-HQ Spain & 78 & 0.07 & 103 & 0.06 & $(-)$ \\
\hline 3) HQ Spain-HQ Spain & 322 & 0.27 & 408 & 0.24 & $(-)$ \\
\hline 4) Plants-Plants & 228 & 0.19 & 619 & 0.36 & $(+)^{* * * *}$ \\
\hline $\begin{array}{l}\text { II. Corporate Network: Operationa } \\
\text { and Strategic Relations }\end{array}$ & 325 & 0.27 & 292 & 0.17 & $(-)^{\star \star \star \star}$ \\
\hline 1) HQ Spain-MNC Plants & 156 & 0.13 & 136 & 0.08 & $(-)^{* * * *}$ \\
\hline 2) HQ Spain-MNC HQ & 118 & 0.10 & 89 & 0.05 & $(-)^{* * * *}$ \\
\hline 3) Plants Spain-MNC HQ & 39 & 0.03 & 14 & 0.01 & $(-)^{* * * *}$ \\
\hline 4) Plants Spain-MNC Plants & 12 & 0.01 & 53 & 0.03 & $(+)^{* * *}$ \\
\hline $\begin{array}{l}\text { III. External Network: Operational } \\
\text { and Strategic Relations }\end{array}$ & 124 & 0.10 & 98 & 0.06 & $(-)^{* * \star *}$ \\
\hline 1) HQ Spain-Clients & 114 & 0.10 & 58 & 0.03 & $(-)^{* * * *}$ \\
\hline 2) Plants Spain-Clients & 12 & 0.01 & 40 & 0.03 & $(+)^{* *}$ \\
\hline
\end{tabular}

a $\hat{p}_{1}$ and $\hat{p}_{2}$ are the proportions of the total relationships in the category.

${ }^{\mathbf{b}}$ Significance of difference of proportions has been calculated using a normal distribution.

$* * * * \mathbf{p}<0,0001 ; * * * \mathbf{p}<0,001, * * \mathbf{p}<0,002$. 


\section{Table 4}

Corporate Nertwork Brakes Spain towards Brakers:

Density Image Matrixes 1998 and 2003

\begin{tabular}{|c|c|c|c|c|}
\hline \multicolumn{4}{|c|}{ Two- mode network density } & $\begin{array}{l}2003 \\
0.156 \\
\end{array}$ \\
\hline \multicolumn{5}{|c|}{ Block Modeling 1998} \\
\hline \multirow{3}{*}{$\begin{array}{l}\text { Brakes } \\
\text { Spain }\end{array}$} & $\begin{array}{c}\text { Brakes } \\
\text { A }\end{array}$ & $\begin{array}{c}\text { Division } \\
\mathrm{B}\end{array}$ & & \multirow{3}{*}{$\begin{array}{l}\text { X Group (Brakes Spain actors): HQ-Product Engineering, HQ-Marketing and Sales, HQ- } \\
\text { Research and Development, HQ-Purchasing. Plant Process Engineering } \\
\text { Y Group (Brakes Spain actors): HQ-Testing, HQ-Controlling, HQ-Purchasing, Plant } \\
\text { Quality, Plant Purchasing, Plant Controlling, Plant General Management, Plant } \\
\text { Manufacturing, Plant Human Resources, HQ-Quality. } \\
\text { A Group (Brakes actors): HQ-Product Engineering, HQ-Research and Development, HQ- } \\
\text { Manufacturing, HQ-Purchasing, HQ-Product Engineering. Plant Product Engineering, } \\
\text { Plant Purchasing. } \\
\text { B Group MNC (Brakes actors): HQ-Marketing and Sales, HQ-Testing, HQ-Human } \\
\text { Resources, HQ-Control, HQ-General Management, HQ-Quality, HQ-Product Engineering. } \\
\text { Plant Quality, Plant Controlling, Plant General Management, Plant Testing, Plant } \\
\text { Research and Development, Plant Process Engineering, Plant Logistics. }\end{array}$} \\
\hline & $X$ & 1 & 1 & \\
\hline & $\mathrm{Y}$ & 0 & 0 & \\
\hline
\end{tabular}

Block Modeling 2003

\begin{tabular}{|c|c|c|c|c|}
\hline \multirow{3}{*}{$\begin{array}{l}\text { Brakes } \\
\text { Spain }\end{array}$} & $\begin{array}{c}\text { Brakes } \\
\text { A }\end{array}$ & \multicolumn{2}{|l|}{$\begin{array}{c}\text { Division } \\
\text { B }\end{array}$} & \\
\hline & $X$ & 1 & 0 & $\begin{array}{l}\text { X Group (Brakes Spain actors):HQ- Product Engineering, HQ-Marketing and Sales, HQ- } \\
\text { Research and Development, HQ-Testing, HQ-Quality, Plant Quality, Plant Process } \\
\text { Engineering. } \\
\text { Y Group (Brakes Spain actors): HQ-Controlling, HQ-Human Resources, HQ-General } \\
\text { Management, } \\
\text { HQ-, Purchasing, Plant General Management, Plant Manufacturing, Plant Human } \\
\text { Resources, Plant Controlling, Plant Logistics. }\end{array}$ \\
\hline & $Y$ & 0 & 0 & $\begin{array}{l}\text { A Group (Brakes actors): Plant Quality, Plant Marketing and Sales, Plant Product } \\
\text { engineering, Plant Process Engineering. } \\
\text { B Group (Brakes actors): HQ-Quality, HQ-Marketing and Sales, HQ-Purchasing, HQ- } \\
\text { Controlling, HQ-General Management, HQ-Testing, HQ-Human resources, HQ-Research } \\
\text { and Development, } \\
\text { HQ Engineering, Plant Controlling, Plant Testing, Plant manufacturing, Plant general } \\
\text { management, Plant Human Resources, Plant Research and Development, Plant } \\
\text { Logistics. }\end{array}$ \\
\hline
\end{tabular}

For the Brakes divisional level actors, plant departments have been consolidated. For instance, Plant Quality is the aggregation of all quality departments of Brakes plants around the world consolidated as one single actor.

\section{Brakes Spain Towards Brakes: Density Matrices per Block}

1998

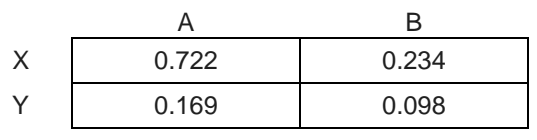

2003

\begin{tabular}{|c|c|c|}
\hline & A & B \\
\hline$x$ & 0.515 & 0.149 \\
\hline Y & 0.070 & 0.096 \\
\hline
\end{tabular}

\section{Number of alter per year}

\begin{tabular}{cccccc}
\multicolumn{2}{c}{} & \multicolumn{2}{c}{1998} & \multicolumn{2}{c}{ Total } \\
\hline $\mathrm{HQ}$ & Plant & $\mathrm{HQ}$ & Plant & $\mathrm{HQ}$ & Plant \\
5 & 2 & 7 & 7 & 12 & 9
\end{tabular}

2003

\begin{tabular}{cccccc}
\multicolumn{2}{c}{ XA } & \multicolumn{2}{c}{ XB } & \multicolumn{2}{c}{ Total } \\
\hline $\mathrm{HQ}$ & Plant & $\mathrm{HQ}$ & Plant & $\mathrm{HQ}$ & Plant \\
0 & 4 & 9 & 7 & 9 & 11
\end{tabular}

To be read: In 1998, the number of departments from Brakes division headquarters to which actors in Block X from Brakes Spain were related, was 5. 
Figure 2

Network Evolution

Internal Network

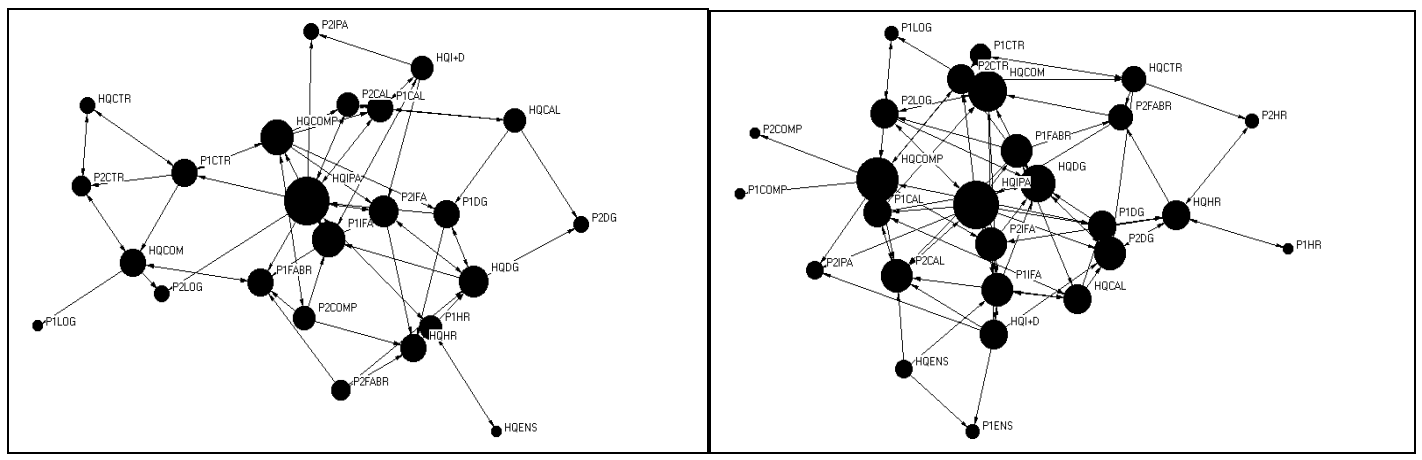

Corporate Network: Two-mode network representation where MNC's functions are one dimension and subsidiary functions are the second dimension. Squares represent MNC's functions and circles represent the subsidiary's functions

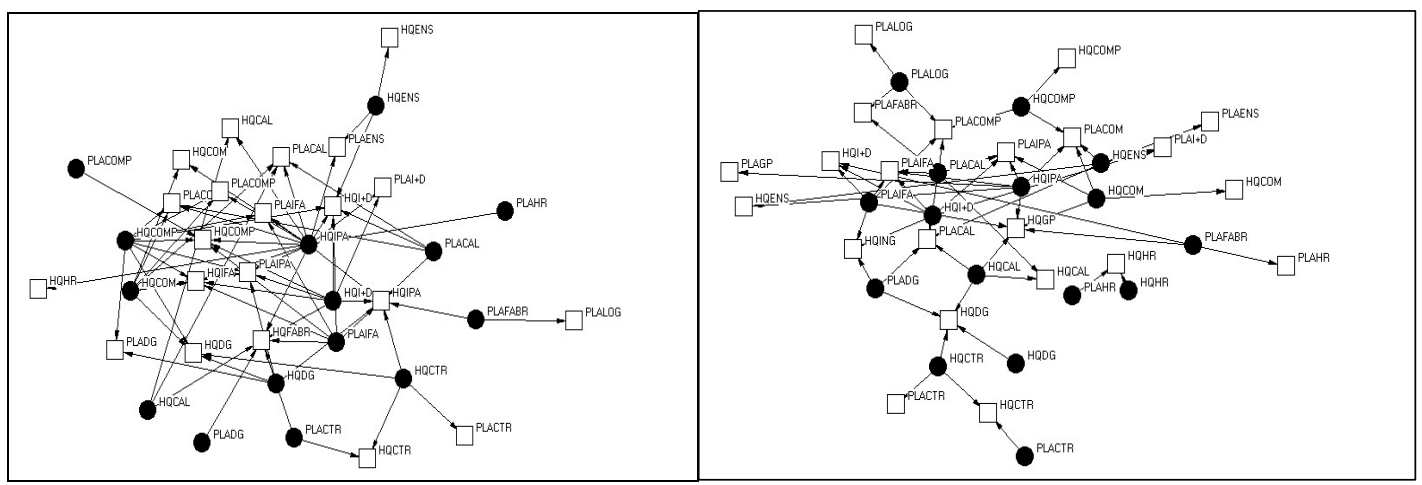

\section{BRAKES SPAIN: THE HISTORY OF ITS STRATEGY}

The story of Brakes Spain is one of a regular subsidiary that was able to gain significance in the strategic development of its mother company. However, Brakes Spain's strategic importance was jeopardized as the MNC centralized key activities. From 1993 to 2003 Brakes Spain suffered initially a rise and then a decline in its strategic importance. Firstly, Brakes Spain moved from being a mere plant to becoming a strategic player within the global company. Then, it started to lose strategic relevance in such a way that its managers perceived the subsidiary was going back to its mere operating role within the MNC. We summarized this story into three different stages or time categories that we have called: Obeying Orders, Gaining Fitness and Losing Ground.

\section{I: Obeying Orders}

Prior to 1998, the business strategy of the MNC British had been one of optimizing operations, reducing costs and minimizing delivery time in a globalized marketplace. The globalization 
process carried out by the MNC had led Brakes Spain to a situation where its customers' decision centers were dispersed worldwide far from its national operations. Moreover, by 1993, Brakes Spain had few local customers and neither proprietary technology nor a team to develop it. This situation stood as a clear disadvantage vis-à-vis other European subsidiaries, which either had relationships with local customers or enough R\&D to cope with developing new products. Managers of Brakes Spain felt its manufacturing operation was a candidate for relocation to a lower labor cost country. In order to overcome this dismal future, the subsidiary decided to design a strategy that allowed Brakes Spain to gain distinctiveness within the division. The subsidiary's CEO summarized this notion as:

"If we were to avoid the plant's relocation, something that was happening to other plants of the group, it was vital for Brakes Spain to be able to add value to the MNC; we decided to transform our unit in order to make it able to make a greater contribution to the division; we wanted to base our prestige in efficiency, the best manufacturing and high flexibility."

The strategy designed to overcome the 'Obey Orders Stage' was based upon three pillars. First, the development of a strong local $\mathrm{HQ}$ in order to improve coordination and knowledge transmission among plants. Fulfilling this function, Brakes Spain expected to serve as a filter between its plants and other units of the MNC. Second, they invested in R\&D subsidiary capabilities, giving emphasis to the engineering department. Several young engineers were recruited with the objective of generating novel manufacturing processes, more efficient plant layout designs, and better product applications. This investment was also expected to indirectly give Brakes Spain a better position compared to similar units in countries such as France and Germany. Should this plan work, Brakes Spain would be able to establish immediate and fluid relationships with both the engineering departments of other units of the MNC and those of its clients. Finally, the strategy aimed at developing the sales department, in order to bring customers closer to Brakes Spain.

In order to compensate for their dull geographic position, Brakes Spain decided to push its sales department to develop the Asian market, hiring international and well-prepared managers who could be in direct touch with customers and engineers of other units of the MNC. They decided to push the production department and their plant managers in order to bargain internally within the MNC to acquire projects and products.

The overall strategy was brought up by the subsidiary, in the form of a suggestion, to the divisional head. The argument used was that the integration of the subsidiary within the group activities, being closer to the customer and the division, would allow Brakes Spain to produce faster, respond quicker and add more value to the division as a whole. Nevertheless, the process followed to gain the division's authorization was quite eclectic. In words of the 1993-1998 CE0:

“...Sometimes you negotiate these things with head office, some they grant and some they don't... sometimes you just don't make a proposal, you simply act and head office endorses it after the fact"

The results of the implemented strategy were evident in 1998, when, as a consequence of sound management by the CEO of Brakes Spain he was promoted to a higher position within the MNC. Additional results attributed to this strategy determined the second stage of Brakes Spain's strategy. 


\section{Gaining Fitness}

By 1998, Brakes Spain had turned the previous situation around. With a share of $11 \%$ of total MNC's turnover, it was the largest subsidiary of the Brakes Division in terms of cash flow contribution to the division. During the 1998-2002 period, several managers from the Spanish subsidiary were promoted to divisional functions and responsibilities. This reveals the contribution potential of the unit within the MNC. Managers' promotions were driven by the perception at Brakes Division that Brakes Spain had become more capable of contributing strategically to the global organization, due to its managers' expertise in operations and business processes. For example, Brakes Spain was able to put a prototype into mass production in record time. What was more, from the selling perspective, customers from distant countries such as the U.S. or Japan would specifically asked to be served by Brakes Spain. Similarly, after a global benchmark process, the MNC decided to clone the task forces model designed by Brakes Spain across the rest of the subsidiaries to launch new products. Furthermore, the MNC decided to 'translate' the layout designs developed by Brakes Spain to the U.S. Additionally, after negotiating with the Brakes Division, plant managers at Brakes Spain were able to gain for the Spanish subsidiary the production of certain parts that were turned down by other units of the MNC. This negotiation left Brakes Spain specialized and responsible of the production of high-margin brakes-system parts within the group.

In sum, Brakes Spain achieved a high reputation across the MNC based upon its manufacturing excellence, its best selling team, its flexibility at launching new products, its well-known engineering team and the fact of being the largest subsidiary of Brakes in terms of net cash contribution. Consider, for instance, the effect that Brakes Spain had on HQ via its involvement in the Asian expansion strategy. In different European meetings, HQ declared the importance of serving Asian customers. However, none of the MNC subsidiaries felt confident enough to overcome problems derived from cultural and language differences and geographic distance. At a certain point in time, the strategy of expanding to Asia seemed impossible. Nevertheless, Brakes Spain pushed its commercial department harder and was able to start projects with one client in Japan and one in Korea, which was the first step to making the Asian expansion feasible.

The strategy proposed in 1999 at Brakes Spain aimed to keep and strengthen the advantageous position achieved. It focused on keeping the state-of-the-art organization and mass production techniques, but added a search for excellence in engineering, to strengthen the identity of the plants, foster good relationships with the workers as well as develop international executives who could aspire to positions at Brakes Division. More than anything else the strategy strengthened their R\&D department by looking for recognition within the group while helping develop the Asian expansion. Nevertheless, the future was going to prove different to that intended.

\section{Losing Ground}

The key change occurred by mid-1998, when a new divisional head was appointed, with subsequent repercussions. His main self-imposed strategic goal was to attack the Asian market through the European operations given their level of technology, efficiency, reliability and geographical location (closer than the U.S., for example). Meanwhile, from the divisional viewpoint of Brakes, it was thought that, in order to achieve this goal, a higher level of centralization was needed. Consequently, by 2002 purchasing, new product launches, 
engineering applications processes and sales activities were centralized. Additionally, the division also imposed a certain level of rationalization at the manufacturing level, trying to leverage specialization of plants. The argued rationale behind these decisions was to keep control over key business activities, to better coordinate R\&D investment among units and to obtain lower manufacturing costs.

This set of measures scaled back the relationships that Brakes Spain had established with customers, as well as with other units of the multinational. The consequences damaged Brakes Spain's autonomous strategic behavior. As global managers and functions were established, local managers and functions started to vanish. Key decisions started to be taken by global managers and only low-level decisions were kept in-country. For instance, under the new structure, Brakes Spain was not allowed to contact a customer directly when the customer decided to include a small change in the design of a new product or application. That function was now the responsibility of the new Global Account Manager, who, in turn, had to coordinate with global project leaders. Apart from losing contact with customers and managers from other units of the MNC, Brakes Spain's field was forced to narrow its strategy towards the achievement of operational excellence. The strong pressure to reduce headcount was unheard of in an organization that had always been focused on customer strategy and growth. In the aftermath, the strategic role played by Brakes Spain vanished under centralized activities such as marketing, sales, new product launches and R\&D. In the words of the 2002-2003 CE0:

"A great part of our reputation within the group was due to our closeness to the customer and the flexibility of our product launching teams. From 2000, when European representatives were appointed to these activities, it is they who were to address the customer, while we could barely reach the customer directly...now we do not control the business and we have gone back to pre-1998: we are simply manufacturing plants.”

\section{A MODEL OF SUBSIDIARY STRATEGY AS EMBEDDEDNESS}

The story of Brakes Spain shows the transition of a marginal unit that shaped its destiny. It did so by taking an active role in building valuable relationships. The subsidiary managers had decided to design a strategy that allowed the unit to gain distinctiveness within the MNC. However, a constraining level of centralization promoted at divisional level in mid-2000 reduced the strategic space that Brakes Spain had enjoyed. It lost its level of autonomy through the centralization of resources and decisions, which counterbalanced the subsidiary's attempts to govern its future.

Underlying this process is a change in the network of relationships from Brakes Spain towards other units of the MNC and its clients. First, it responded to operational integration by developing a network of relations, generating Operational Embeddedness. Second, it leveraged its operational efficiencies into distinctive capabilities establishing relations across the MNC, generating Capability Embeddedness. These capabilities, in turn, helped to develop a strategic role, as Brakes Spain championed new markets and developed new products and processes copied across the MNC, reaching Strategic Embeddedness. In the last stage, they lost control over key business processes through centralized key activities and went back to Operational Embeddedness. Each embeddedness type was built on the previous one. Next, we will describe each of the constructs that make the theoretical model proposed that emerged from the study data as shown in Figure 1. 


\section{Operational Embeddedness}

By operational embeddedness we mean the set of relations between Brakes Spain and the rest of the MNC that involve operational and manufacturing activities. As can be seen in Table 2, for Stage I, the subsidiary concentrated in developing efficiencies in operation, manufacturing and coordination amongst plants. In a similar fashion towards the end of this study, operational embeddedness was prevailing. This is reflected in the significance of the relationships among Spanish plants (36\% of all the relations) and the increased significance of the relations between the Spanish plants and those of the customers (3\% of all relations) (See Table 3). Operational embeddedness is highlighted in table 4 as most of the relations appearing in the only non-zero block in 2003 are towards units in other divisional plants (block density $=0.515$ ). As the data in this study suggests, operational embeddedness implies more relationships among plants within the division and a lower level of relations between local HQ and divisional HQ.

\section{Capability Embeddedness}

Capability embeddedness is the set of relationships resulting from efforts to further develop MNC's strategic capabilities. Brakes Spain was first able to develop operational embeddedness through its increasing participation both in best-practice transfer from Brakes Spain, and its participation in general best-practice workgroups within the MNC. Best-Practice transfers were informally developed by Brakes Spain by sharing their know-how. Work group relations emerged as other units in the MNC asked for them. Next, the subsidiary was able to develop its own capability in product development through recruitment of R\&D and engineering staff. Coupled with development, they built a sales department that would work in tandem with R\&D and Engineering, catering to specific customer requirements. This structure, together with manufacturing excellence, increased its position to capability embeddedness as shown by the data in Table 2. This observation is supported by the network measurement in 1998 of a high number of interactions between Brakes Spain and customers, as shown in Table 3.

The non-zero value of the XB block in the 1998 block model highlights the existence of relationships between Brakes Spain and different departments in Brakes Division, both at the plant and the HQ level. The fact that all those relations came from the Brakes Spain head office illustrates how those were purposefully managed by top management in Brakes Spain's head office (see table 4). Through this process Brakes Spain became an integral part of strategic capability development in the division.

\section{Strategic Embeddedness}

By strategic embeddedness we mean the set of relations that Brakes Spain established with other units of the MNC and with Brakes Division. The fact that Brakes Spain had consistently good performance within Brakes, had developed distinctive capabilities and gained customer recognition, made them a significant player within the MNC. They were perceived as a set of skillful executives who had transformed their organization (see Table 2). Their intention of developing a distinctive character to avoid being relocated had reached fruition when their structure to serve customers was copied across the MNC, but more importantly when they acted as the flagship to break into the Asian market. This pattern is also shown by the social network analysis. Table 4 shows that the number of alters in 1998 was higher among Brakes' HQ

16 - IESE Business School-University of Navarra 
departments than among other subsidiaries' departments. Their relations with the MNC at the level of HQ and Plants were significantly higher in 1998 as shown in Table 3. Moreover, the number of relationships of the entire Corporate Network was significantly higher in 1998, when Brakes Spain reached its strategic embeddedness peak. Overall, strategic embeddedness was developed through the increased presence and relevance in the MNC strategic forums, which is shown in different patterns of relations within the MNC.

\section{HO Mandate versus Subsidiary's Autonomous Behavior}

For the subsidiary to present autonomous behavior, the HQ mandate must allow it. The evidence from the case presented here clearly shows that HQ allowed Brakes Spain to behave autonomously (see Table 2). Perhaps more important was that the subsidiary capitalized on this leeway, building a vast network across the MNC and with external entities. Table 4 shows that there was a higher density in 1998 between Brakes Spain strategic departments and the MNC than in 2003, illustrating a retrenchment of subsidiary behavior in its international relations. Between 1998 and 2003, Brakes Spain intensified the relations among its units while significantly decreasing the effort to relate to other units in the MNC as the percentage of overall relations between Brakes Spain and Brakes or its customers decreased significantly (see Table 3). This insight can be summarized in the following propositions:

Proposition 1a: Restrictive mandates from HQ are negatively associated with the subsidiary's autonomous behavior.

Proposition 1b: Autonomous behavior is positively associated with the subsidiary's generation of capabilities and strategic levels of embeddedness.

\section{From Operational to Capability to Strategic Embeddedness}

As the subsidiary was leeway allowed to develop relationships with customers and other units of the MNC, Brakes Spain was first able to develop operational embeddedness, engaging in quality control with other units of the MNC (see Table 2). Next, the subsidiary through recruitment of R\&D and engineering staff was able to develop its own capabilities, increasing its relations with the MNC capability embeddedness. This sequence suggests that constructing embeddedness is a process in which establishing one level of embeddedness makes possible to build the next level. In the case of Brakes Spain, initial operational efficiency and establishing a strong Internal Network led to building new capabilities and establishing a Corporate Network. Then, the subsidiary was able to develop Strategic Embeddedness by gaining influence in the overall decision making within Brakes. As the subsidiary grew into developing its own strategy, it gained distinctiveness within the MNC. Network data for 1998 shows that the External Network was more dense and with a significantly higher proportion of relations (see Tables 3 and 4). As data shows in Table 5, operational embeddedness led to capability embeddedness and then to strategic embeddedness. The argument of the model presented is that in order to move to one you have to have proficiency in the previous level of embeddedness. Conversely, as shown in Table 5, when centralization of activities was imposed, the network of relations was scaled back for Brakes Spain. It is significant that the number of alters in Brakes Spain's network from Brakes' HQ decreased from 12 to 9, while the relations with alters belonging to other MNC plants increased from 9 to 11 (see Table 4). Moreover, most of the

IESE Business School-University of Navarra - 17 
relationships to HQ's functions came from their plant equivalents. The decreasing role of the Brakes Spain head office in this last phase of the study illustrates the way back to operational efficiency. Operational embeddedness emphasizes "operational excellence". This term was used by the 1993-1998 CEO as his motto and was again reclaimed by the 2000-2003 CEO as the instruction to his local managers. Operational excellence is reflected in the higher importance of 2003 relations within Brakes Spain (77\% of all relations in Table 3). Once again Brakes Spain was left with operational embeddedness. This observation can be summarized in the following propositions:

Proposition 2a: Establishing operational embeddedness is a necessary condition for the subsequent achievement of capability embeddedness.

Proposition 2b: Establishing operational embeddedness is a necessary condition for the subsequent achievement of strategic embeddedness.

Proposition 2c: A restraining mandate from HQ is negatively associated with the achievement of capability or strategic embeddedness.

\section{Table 5}

Interaction of Roles of $\mathrm{HQ}$ and Subsidiary Determine Type of Embeddedness

\begin{tabular}{|c|c|c|c|c|c|}
\hline Period & $\begin{array}{l}\text { HQ's } \\
\text { Stance }\end{array}$ & $\begin{array}{l}\text { Brakes } \\
\text { Spain's } \\
\text { Stance }\end{array}$ & $\begin{array}{l}\text { Relations } \\
\text { of Brakes } \\
\text { Spain }\end{array}$ & $\begin{array}{c}\text { Subsidiary } \\
\text { Distinctiveness }\end{array}$ & Examples of Significant Events ${ }^{a}$ \\
\hline $\begin{array}{l}\text { I. Obeying } \\
\text { Orders } \\
1993-1998\end{array}$ & Indifferent & $\begin{array}{l}\text { Operational } \\
\text { effectiveness }\end{array}$ & Internal & $\underline{\text { Low }}$ & $\begin{array}{l}\text { One of the plants is granted the status of Global } \\
\text { Product Center by HQ. The reasons are: high know } \\
\text { how, high dynamism between subsidiary's units, } \\
\text { control on manufacturing and training } \\
\text { Manufactured products are designed in Germany, } \\
\text { the U.K. and France. The local engineering team is } \\
\text { skilled, but only in solving technical problems, not in } \\
\text { design or training. }\end{array}$ \\
\hline $\begin{array}{l}\text { II. Gaining } \\
\text { Fitness }\end{array}$ & Open & $\begin{array}{l}\text { Capability } \\
\text { development }\end{array}$ & $\begin{array}{l}\text { Internal } \\
\text { and } \\
\text { corporate }\end{array}$ & $\underline{\text { Medium }}$ & $\begin{array}{l}\text { Increased investment in engineering, basically in } \\
\text { recruiting new talent for new products. This was in } \\
\text { part negotiated with HQ, but mostly Brakes Spain } \\
\text { preferred to say "sorry" rather than to ask for } \\
\text { permission in a highly political environment. Brakes } \\
\text { Spain is relatively small, so it is not perceived as } \\
\text { troublesome at HQ. }\end{array}$ \\
\hline 1998-2002 & Open & $\begin{array}{c}\text { Strategic } \\
\text { development }\end{array}$ & $\begin{array}{l}\text { Internal, } \\
\text { corporate } \\
\text { and } \\
\text { external }\end{array}$ & $\underline{\text { High }}$ & $\begin{array}{l}\text { Coupling R\&D and sales, Brakes Spain is able to } \\
\text { work developing product with the customer. The } \\
\text { intention is to launch new products to satisfy the } \\
\text { customer, maintaining excellence in operations and } \\
\text { in processes. Accepted by HQ, the intention is } \\
\text { realized to an extent such that Brakes Spain } \\
\text { outperforms all other units of the MNC. }\end{array}$ \\
\hline $\begin{array}{l}\text { III. Losing } \\
\text { Ground } \\
\text { 2002-2003 }\end{array}$ & Restrictive & $\begin{array}{l}\text { Left only with } \\
\text { operational } \\
\text { effectiveness }\end{array}$ & Internal & $\underline{\text { Medium }}$ & $\begin{array}{l}\text { Centralization of engineering together with } \\
\text { centralization of relationships with customers at } \mathrm{HQ} \\
\text { leaves Brakes Spain defenseless. Joint action of } \\
\text { sales and engineering is copied from Brakes Spain } \\
\text { to } \mathrm{HQ} \text {, as the best way to serve the customer and } \\
\text { most employees go to HQ. }\end{array}$ \\
\hline
\end{tabular}

\footnotetext{
${ }^{a}$ Key events have been extracted from interview, participant observation and archival data to deduce the chain of evidence.
} 


\section{Levels of Embeddedness as the Subsidiary Strategy}

All in all, the evidence suggests that Brakes Spain gained distinctiveness within the MNC via generation of embeddedness and then, lost it by mandate of HQ (see Table 5). High and medium distinctiveness are associated with capability and strategic embeddedness. Network analysis strengthens the evidence suggesting that decline in subsidiary distinctiveness was forced through the loss of relations within the corporate and External Network (see Table 3). Similarly, the previous strategic development suggests that the mechanism used by Brakes Spain to develop strategy was an increase in relations. The relationships that the subsidiary developed with the MNC and customers were the vehicle for developing their own strategy. The next proposition is the synthesis of this observation.

Proposition 3: Capability and Strategic embeddedness are positively associated with the subsidiary strategic distinctiveness within the MNC.

The situation for 2003 is radically different to that of 1998, when Brakes asked the Spanish subsidiary to replicate its new product launch organization for the whole MNC. Evidence in Table 5 suggests that Brakes Spain lost its distinctiveness as it lost its capability and strategic embeddedness. While these two levels were present, their strategy reinforced autonomous behavior encouraging new product development and the search for new business. When HQ curtailed their strategy and enforced subsidiary compliance instead of subsidiary distinctiveness, the feedback did not encourage autonomous behavior. This observation is synthesized in proposition 4 .

Proposition 4: The acceptance of subsidiary's level of distinctiveness by the MNC's HQ is positively associated with higher levels of autonomous behavior.

\section{COMMENTS AND CONCLUSIONS}

We have developed a model of subsidiary strategy that presents embeddedness as the key driver for the subsidiary to generate distinctiveness within the MNC. We have also identified three levels of embeddedness that can create distinctiveness for the subsidiary within the MNC. Our results complement existing research in subsidiary strategy (Birkinshaw and Hood, 1998; Taggart, 1999; Andersson et al., 2002), which identifies the ability of the subsidiary to develop strategy.

For Andersson et al. (2002) external embeddedness is critical for subsidiary strategy development and does have a significant impact on subsidiary performance. We complement their findings; we add to them the criticality of internal embeddedness. To their claim regarding external embeddedness, our paper adds the importance of three different levels of internal embeddedness to the development of subsidiary distinctiveness.

Birkinshaw and Hood (1998) emphasize the importance of interaction between the development of subsidiary capabilities and HQ's mandate in explaining subsidiary evolution. The model presented in this paper builds on their development by emphasizing that the subsidiary capability evolution flows through different levels of embeddedness, which respond not only to HQ's mandate but also to the subsidiary's autonomous behavior. Operational embeddedness grows parallel with the development of basic operational capabilities. The integration of the multinational's worldwide operations implies a minimum level of operational capabilities for 
global coordination to work efficiently. When the subsidiary has achieved a certain level of integration, the development of strategic capabilities allows to contribute to the worldwide learning effort emphasized by Bartlett and Ghoshal (1989), increasing their level of capability embeddedness. As recognition grows around the MNC, the subsidiary might start to gain a voice in different issues, achieving a certain level of strategic influence through the development of strategic embeddedness. As such, the evolution of the capabilities of the subsidiary parallels the evolution through the three different levels of embeddedness identified in this paper. The model presented here also acknowledges the critical relationship between headquarters and subsidiary (Taggart, 1999; Andersson et al., 2005), by including it as a triggering element. Moreover, as the different stages of embeddedness are developed, subsidiary distinctiveness influences further autonomous behavior.

The influence of the network position of firms on their performance has been widely recognized (Zukin and DiMaggio, 1990; Uzzi, 1996; Dyer and Singh, 1998; Håkansson and Snehota, 1998; Gulati et al., 2000; Rowley et al., 2000; Hung, 2002). Birkinshaw and Morrison (1995) translate this view into the multinational context emphasizing the importance of lateral relationships between subsidiaries, that have been found to have a significant influence on performance (Subramaniam and Watson, 2006). This paper applies this view to the MNC network view (Ghoshal and Bartlett, 1990; Andersson and Forsgren, 1996) identifying network embeddedness as the foundation on which the subsidiary can build its distinctiveness within the MNC. The model in this paper emphasizes that these lateral contributions can be designed in order to become a specialized contributor, initiating non-specified mandates. It also explains how these interdependencies are created and introduces a logical sequence for embeddedness evolution.

The model presented here centers on the ability of the subsidiary to develop its own strategy, and in doing so, affecting MNC's norms and, particularly, its strategy. Although the power to design a strategy for the subsidiary may be breed in HQ, conflicting logic or interests from the subsidiary may reshape both the subsidiary and the MNC strategy. Social action by the subsidiary is not only shaped and conditioned by the context of action, determined by HQ and the action of other subsidiaries, but also by the dynamic element of social action itself. If the subsidiary is able to exercise strategic choice by developing an active role, this proactive behavior may affect not only the subsidiary but may expand its effect to the whole MNC. This may be particularly important when the strategy promoted by the MNC endangers the existence of the subsidiary itself. The overall level of distinctiveness a subsidiary may be capable of generating will depend on how the subsidiary manages the three types of embeddedness.

Caution must be exercised in discussing the results of the present study. First, it has been carried out within a Spanish context and cultural elements could be partial explanation of our findings. Second, Brakes' network effect tends to be industry specific (Rowley et al., 2000), and a single case only addresses one industry. Third, being a single case study, conceptual generalization has been attempted through the model presented. Although we have used quantitative data to supplement our analysis, the use of qualitative data entails interpretation. While this approach is very powerful for developing a theory, it does not provide unequivocal results. Although known precautions have been taken to strengthen validity and reliability, further quantitative designs in future research can strengthen the framework and concepts presented here.

All in all, while the literature on subsidiary strategy has traditionally value in focused on the role it plays within the multinational company, no work, to our knowledge, has operational zed the concept of embeddedness in concrete strategic and organizational issues. We introduce a new and critical component for subsidiary strategy. The three dimensions of embeddedness that 
we propose correspond to three basic dimensions that result in subsidiary distinctiveness. Although we do not claim to reduce all components of subsidiary strategy to managing its embeddedness level, the concept of developing embeddedness to gain distinctiveness explains a process through which subsidiaries can develop a strategy. 


\section{References}

Andersson. U. and M. Forsgren (1996), "Subsidiary embeddedness and control in the multinational corporation,” International Business Review, 5, (5), pp. 487-508.

Andersson, U., I. Björkman and M. Forsgren (2002), "Explaining subsidiary network embeddedness: The impact of headquarters control mechanisms," (Working paper),

Andersson, U., I. Björkman and M. Forsgren (2005), "Managing subsidiary knowledge creation: The effect of control mechanisms on subsidiary local embeddedness," International Business Review, 14, (5), pp. 521-538.

Bartlett, C. and S. Ghoshal (1989), "Managing across borders: The transnational solution," Harvard Business School Press, Boston, Massachusetts.

Birkinshaw, J. (1997), "Entrepreneurship in multinational corporations: The characteristics of subsidiary initiative,” Strategic Management Journal, 18, (3), pp. 207-229.

Birkinshaw, J. and A. Morrison (1995), "Configurations of strategy and structure in subsidiaries of multinational corporations," Journal of International Business Studies, 26, (4), pp. 729754.

Birkinshaw, J. and N. Hood (1998), "Multinational subsidiary evolution: Capability and charter change in foreign-owned subsidiary companies," Academy of Management Review, 23, (4), pp. 773-795.

Birkinshaw, J., N. Hood and S. Young (2005), "Subsidiary entrepreneurship, internal and external competitive forces, and subsidiary performance," International Business Review, 14, (2), pp. 227-248.

Borgatti, S. and M. Everett (1997), "Network analysis of two mode data," Social Networks, 19, pp. 243-269.

Burgelman, RA. (1983), "A process model of internal corporate venturing in the diversified major firm,” Administrative Science Quarterly, 28, (2), pp. 223-244.

Delany, E. (2000), "Strategic development of the multinational subsidiary through subsidiary initiative-taking," Long Range Planning, 33, (2), pp. 220-244.

Dyer, J. and H. Singh (1998), "The relational view: Cooperative strategy and sources of interorganizational competitive strategy," Academy of Management Review, 23, p. 660.

Freeman, L., AK. Romney and SC. Freeman (1987), "Cognitive structure and information accuracy," American Anthropologist, 89, pp. 310-325.

Ghoshal, S. and C. Bartlett (1990), "The multinational corporation as an interorganizational network," Academy of Management Review, 15, (4), pp. 603-625.

Granovetter, M. (1985), "Economic action and social structure. The problem of embeddedness," American Journal of Sociology, 91, pp. 481-510.

Gulati, R., N. Nohria and A. Zaheer (2000), "Strategic networks," Strategic Management Journal, 21, (3), pp. 203-215. 
Håkansson, H. and I. Snehota (1998), "No business is an island. The network concept of business strategy," Scandinavian Journal of Management Studies, 4, (3), pp. 187-200.

Hedlund, G. (1986), “The hypermodern mnc: A heterarchy?," Human Resource Management, 25, (1), pp. 9-35.

Hung, SC. (2002), "Mobilising networks to achieve strategic difference," Long Range Planning, 35, pp. 591-613.

Jarillo, C. and J. Martínez (1990), "Different roles for subsidiaries: The case of multinational corporations in Spain," Strategic Management Journal, 11, (7), pp. 501-512.

Knoke, D. and JH. Kuklinski (1982), “Network anaylisis,” Sage, Newbury Park.

Miles, MB. and AM. Huberman (1994), "Qualitative data analysis: An expanded sourcebook," ( $2^{\text {a }}$ ed.). Sage, Thousand Oaks, CA.

Nohria, N. and S. Ghoshal (1997), "The differentiated network: Organizing multinational corporations for value creation," Jossey-Bass Publishers, San Francisco, CA.

Pentland, B. (1999), "Building process theory with narrative: From description to explanation," Academy of Management Review, 24, (4), pp. 711-724.

Prahalad, CK., and YL. Doz (1981), “An approach to strategic control in mncs," Sloan Management Review, Summer, pp. 5-13.

Rowley, T., D. Behrens and D. Krackhardt (2000), "Redundant governance structures: An analysis of structural and relational embeddedness in the steel and semiconductor industries," Strategic Management Journal, 21, (3), pp. 369-386.

Scott, J. (1991), “Social network analysis: A handbook,” Sage, Newbury Park, California.

Silverman, D. (2001), "Interpreting qualitative data: Methods for analysing talk, text and interaction," ( $2^{\text {a }}$ ed.), Sage, London.

Subramaniam, M. and S. Watson (2006), "How interdependence affects subsidiary performance," Journal of Business Research, 59, pp. 916-924.

Taggart, JH. (1999), "Subsidiary strategy: Concepts, empirical evidence,and policy implications," International Business Review, 8, (2), pp. 121-124.

Taggart, JH. and N. Hood (1999), "Determinants of autonomy in multinational corporation subsidiaries,” European Management Journal, 17, (2), pp. 226-236.

Teece, DJ., G. Pisano and A. Shuen (1997), "Dynamic capabilities and strategic management," Strategic Management Journal, 18, pp. 509-533.

Uzzi, B. (1996), "The sources and consequences of embeddedness for the economic performance of organizations," American Sociological Review, 61, pp. 674-698.

Wasserman, S. and K. Faust (1999), "Social network analysis," Cambridge University Press, Cambridge.

Womack, JP., DT. Jones and D. Roos (1991), "The machine that changed the world: The story of lean production," Harper Collins Pub, New York. 
Yin, RK. (1994), “Case study research: Design and methods,” (2ª ed.), Sage, London.

Zukin, S. and P. DiMaggio (1990), "Introduction," in P. DiMaggio (ed.), "Structures of capital: The social organization of the economy," Cambridge University, Cambridge, pp. 1-36. 